\title{
Influence of Child Neglect on Self-concept of Senior Secondary School Students in Cross River State, Nigeria
}

\author{
Ajake, Uchenna Egodi (PhD)
}

Institute of Education

University of Calabar

Ucheajake@gmail.com

\author{
Oden, Sarah Nicholas (PhD) \\ Department of Curriculum \& Teaching \\ University of Calabar, Calabar \\ Salnoden@yahoo.com
}

Bisong, Nonso .N. (PhD)

Department of Educational foundation, Guidance \& Counseling, University of Calabar nonny3000@yahoo.com

\section{Doi:10.5901/jesr.2014.v4n3p239}

\begin{abstract}
This study was to determine the influence of child neglect on the self concept of senior secondary school students in Cross River State, Nigeria. The research design was survey design. The sample size consisted of two thousand (2000) senior secondary two (SS II) students. The instrument for data collection was questionnaire captioned Child Neglect Questionnaire (CNQ) and Students Self-concept Questionnaire (SSCQ). One Way Analysis of Variance was used for data analysis and the hypothesis was tested at 0.05 alpha level. The result obtained showed a significant negative influence of child neglect on the self- concept (in terms of physical self, social self, moral self, financial self and family self) respectively.
\end{abstract}

Keywords: Child Neglect, Students, Self-Concept, Cross River, Influence.

\section{Introduction}

The senior secondary school student self-concept are related to their relationship with parents and significant others. Conger (1977) sees parents as very significant people in the lives of most secondary school students and so their relationship with these adolescents is one factor that determines how they will develop their self-concept.

Sheslow, Taylor and Luken (2005) observed that, a healthy self-concept is the child's amour against challenges of the world. Children who feel good about themselves seem to have an easier time handling conflict and solving thought provoking problem. Such children are realistic and generally optimistic. In contrast, most children in our Secondary Schools especially in Cross River state exhibited low self-esteem. Thus, challenges can constitute a source of major anxiety and frustration for them. Such children have a hard time finding solutions to problems. If they are plugged with self-critical thoughts, they may become passive, withdrawn or depressed. (Ajake, Ukpong and Jamabo 2011).

Robson (1988) defined self concept as the sense of contentment and self acceptance that stems from person's appraisal of his or her own worth, significance, attractiveness, competence and ability to satisfy aspiration. It encompasses the extent to which individuals feel comfortable with the sense they have of themselves and to a lesser extent, their accomplishment and how they believe they are viewed by others. It is one's overall assessment of one's worth as a person. (Weiten; Lloyd; Dunn and Hammer 2009).

Hence, good parental care usually serves as a guarantee for the development of healthy self-concept. It is therefore important that parents and caregivers should give adequate attention, love and care to their children. Childhood should be entitled to special care and assistance for full and harmonious development of his or her personality. But the paradox of this is that the $21^{\text {st }}$ century world, some parents and caregivers still see the relationship with their children as 
a paradigm of the old concept of "spare the rod and spoil the child". Parents and caregivers are seen maltreating, neglecting or even failing to provide the necessary love, care and attention necessary for the child's normal healthy personality development. (Ajake et al 2011 \& Isangedighi, Ajake and Bisong 2009).

Records abounds showing how malnourished, weak and unkempt children were traded away by parents or family members for economic gains or as sheer means of getting rid of them. For example, Ebigbo (1990) reveals that the International labour organization declared that not less than 10 million African children under the age of 15 years are neglected. One's worry is not so much that this dark spot exists in parent-child relationship, what is worrisome is its persistence globally in spite of advancement in human civilization. Of great interest is the United Nations study in the 1990 which showed the following distressing figures: that 100 million children subsist only by engaging in back-breaking work, petty crime, prostitution or begging; over 50 million children work under unsafe or unhealthy conditions; 120 million children between the ages of six and eleven are deprived of schooling some 3.5 million children die from preventable or curable diseases, some 115 million children under 5 years in developing countries live in conditions of absolute poverty; untold millions of children are maltreated, neglected or become victims of drug abuse (Dada, 2002).

The difference between a child and an adult was believed to be only quantitative. Children were scarcely considered worthy of recognition. Children had no say in family affairs, and toys were initially the properties of adult. They were expected to do the same kind of jobs adults did without considering their energy level and nutritional needs. Children were dressed shapelessly in adults clothes and books were not produced specifically for them until the $19^{\text {th }}$ century (Ajake et al 2011).

Several definitions have been proposed. Most commonly emphasized seen child neglect as the inability to provide child's basic developmental needs by act of omission by those responsible for the child. The broadest definition of neglect proposed by Dubowitz(2004) is an unelaborated "the basic needs of the child are not met". Early definitions focused on physical neglect, such as inadequate living environment, personal hygiene or nutrition perhaps because this type of neglect is not readily apparent. (James, 2000a).

Definitions have since expanded to include multiple categories such as supervisory neglect, abandonment or desertion, and educational or medical neglect. Psychological and emotional neglect have been added which are less easy to recognize and quantify. However, May-Chahal \& Cawson, 2005). Indicated that it is difficult to define the point on the continuum of duty of care at which behavior becomes neglectful. Some definitions suggest differentiating chronic or persistent neglect from episodic, reactive or transitory neglect. This differentiation recognizes that some parents may struggle to deliver appropriate care at times of crisis and there is an implicit cultural tolerance of rarely occurring neglectful behavior for parents, all of whom may be occasionally inattentive (Tanner \& Turney, 2003; Straus \& Kantor, 2005). Chronic neglect, on the other hand is characterized by an ingrained sense of hopelessness in the parents and unremitting low level of care for the children. It can also be argued that even a single incident can constitute neglect. For example, leaving a pre-schooler unsupervised for several hours is neglectful behavior whether it is a single incident or has occurred several times (Zuravin, 1999).

Thus, a child is neglected if, within cultural expectations, his or her developmental needs are not met by those responsible regardless of intent, culpability, or social or ethnic background.

Also, Department of health in United Kingdom emphasizes chronicity. Neglect is seen as a persistent failure to meet a child's basic physical and or psychological needs likely to result in the serious impairment of the child's health or development. This may involve a parent or caregiver failing to provide adequate food, shelter or clothing, failing to protect a child from physical harm or danger, or failure to ensure access to appropriate medical care or treatment or child's basic emotional needs. (Department of Health-Working Together definition, 1999, P.6 cited in Tanner \& Turney, 2003).

Child neglect according to Sullivan (2000) categorized them into the following

- Physical: with subcategories of general neglect (e.g failure to provide adequate food, clothing and shelter), medical neglect, abandonment and expulsion.

- Supervisory neglect: related to inadequate supervison dependent on the age of the child involved.

- Emotional neglect: with subcategories of inadequate nurturance or affection, chronic or extreme spousal abuse, permitted drug or alcohol use, permitted maladaptive behavior, refusal of psychological care, delay in psychological care or other emotional neglect.

- Educational neglect: with subcategories of permitted or chronic truancy, failure to enroll or inattention to special educational need.

A study by Chapple; Tyler \& Bersani (2005). Examined the relationship of child neglect with self-control and peer rejection. Using prospective, longitudinal data from a community sample found that child neglect adversely affects peer rejection and violence. Neglected children were more likely to be rejected by their peers and invariably have negative self 
concept. Experience with child neglect has been suggested to interfere with healthy self-concept and behavioural development (Egeland, Yates, Appleyard \& van Dulman 2002; Manghan \& Cicchetti,2002; Bolger \& Patterson, 2001).

As such, neglected children experience parent-child interaction, which are often devoid of attention and caring and subsequently are unlikely to develop healthy self concept. DeMuth (2004; Bolger and colleagues 1998; Depaul \& Arruabarrena 1995) argue that physical environment of neglected families (e.g homes being extremely dirty) may discourage children from inviting friends over, which leads to those children having difficulties establishing and maintaining relationships and thus are more at risk of developing negative self-concept later in life.

Despite the significant increase in emotional and physical neglect, in recent years (Sedlack \& Broadhurst 1996), child neglect has received limited attention in literature (Crouch and Milner, 1993; Depaul \& Arruabarrena, 1995). The few studies on neglect that do exist, however have found positive link between neglect and peer rejection (Bolger \& Patterson, 2001) was associated with a high risk of rejection by peers. The duration of maltreatment also positively influenced the child being rejected by peers over time. Overall, research tends to find that children who are subjected to all forms of neglect have poorer outcome compared to non neglected children.

Unfortunately, children who have been neglected are prone to internalizing problems such as low-self esteem, depression, social withdrawal, apathy, passivity and helplessness. They have difficulties with interpersonal relationship. Neglected children lack the ability to participate fully in society as adults. (Ajake, et al 2011). The purpose of this research was to determine the influence of child neglect on the self-concept of Senior secondary school students in Cross River state, Nigeria.

\section{Methodology}

Subjects: Simple and stratified random sampling technique was used in school and subject selection. Two thousand students were randomly selected from twenty secondary schools in Cross River state, Nigeria for the study. The subjects were made up of 1000 males and 1000 females respectively.

\section{Instrumentation}

The instrument for data collection was questionnaires captioned Child Neglect Questionnaire (CNQ) and Students SelfConcept Questionnaire (SSCQ). The instrument had three sections A-C. section "A" elicited from the respondents demographic information such as age, sex, school type and class. Section "B" was a five item 4 point Likert type scale that measured the extent of child neglect while section " $C$ " was a 20 item 4 point Likert-type scale that measured the respondents self-concept such as social-self, physical-self, moral-self, financial-self and family-self. The researchers visited each of the sample schools having obtained informed consent, assembled the subjects selected in the classroom and administered the copies of the questionnaires to them. A total of 2000 copies of questionnaires were administered out of which 1973, were properly filled and returned.

\section{Data Analysis}

The data generated were analyzed with One Way Analysis of Variance (ANOVA). The hypothesis was tested at 0.05 level of significance.

The subjects were categorized into those who were highly ,moderately or lowly neglected based on the scores obtained. Table 1 shows the means scores and standard deviation of respondents in self concepts across levels of child neglect. While Table 2 shows the actual Analysis of variance; influence of child neglect on self concept and table 3 shows the Fishers' Least significance Difference (LSD) multiple comparison analysis. 
Table 1: Mean scores and Standard Deviations of Respondents in Self-Concept across Levels of Child Neglect.

\begin{tabular}{|c|c|c|c|c|c|}
\hline$S / N$ & Variables & $\begin{array}{c}\text { Group } \\
\text { (Level of abuses) }\end{array}$ & \\
\hline \multicolumn{3}{|c|}{ 1. Social Self-Conceptlow level } & 672 & 9.33 & 2.17 \\
\hline & & Moderate level & 539 & 7.33 & 2.14 \\
\hline & & High level & 762 & 5.92 & 1.69 \\
\hline & & Total & 1973 & 7.47 & 2.46 \\
\hline \multirow[t]{4}{*}{2.} & Physical Self-Concept & Low level & 672 & 11.29 & 2.89 \\
\hline & & Moderate level & 539 & 7.88 & 2.82 \\
\hline & & High level & 762 & 5.96 & 1.71 \\
\hline & & Total & 1973 & 8.30 & 3.37 \\
\hline \multicolumn{3}{|c|}{ 3. Moral Self-ConceptLow level } & 672 & 9.88 & 2.34 \\
\hline & & Moderate level & 539 & 8.32 & 2.45 \\
\hline & & High level & 762 & 6.52 & 1.98 \\
\hline & & Total & 1973 & 8.16 & 2.66 \\
\hline \multirow[t]{4}{*}{4.} & Financial Self-Concept & Low level & 672 & 8.89 & 2.92 \\
\hline & & Moderate level & 539 & 6.37 & 2.31 \\
\hline & & High level & 762 & 5.07 & 1.27 \\
\hline & & Total & 1973 & 6.73 & 2.77 \\
\hline \multirow[t]{4}{*}{5.} & Family Self-Concept & Low level & 672 & 11.13 & 2.31 \\
\hline & & Moderate level & 539 & 9.69 & 2.34 \\
\hline & & High level & 762 & 7.79 & 2.08 \\
\hline & & Total & 1973 & 9.45 & 2.65 \\
\hline & Overall Self-Concept & Low level & 672 & 50.53 & 8.56 \\
\hline & & Moderate level & 539 & 39.60 & 8.67 \\
\hline & & High level & 762 & 31.26 & 5.73 \\
\hline & & Total & 1973 & 40.10 & 11.20 \\
\hline
\end{tabular}

Table 2: Analysis of Variance; Influence of Child neglect on Self-Concept of Senior Secondary School Students.

\begin{tabular}{|c|c|c|c|c|c|}
\hline Variable & $\begin{array}{l}\text { Source of } \\
\text { Variation }\end{array}$ & $\begin{array}{l}\text { Sum of } \\
\text { Square }\end{array}$ & df & $\begin{array}{c}\text { Ms } \\
\text { (mean square) }\end{array}$ & $\mathbf{F}$ \\
\hline Social Self- & Between group & 4163.988 & 2 & 2081.994 & $524.817^{*}$ \\
\hline \multirow[t]{2}{*}{ Concept } & Within Group & 7815.153 & 1970 & 3.967 & \\
\hline & Total & 11979.141 & 1972 & & \\
\hline Physical Self- & Between Group & 10269.377 & 2 & 5134.688 & $834.312^{*}$ \\
\hline \multirow[t]{2}{*}{ Concept } & Within Group & 12124.160 & 1970 & 6.154 & \\
\hline & Total & 22393.537 & 1972 & & \\
\hline Moral Self- & Between Group & 4058.231 & 2 & 2029.115 & $404.437^{*}$ \\
\hline \multirow[t]{2}{*}{ Concept } & Within Group & 9883.747 & 1970 & 5.017 & \\
\hline & Total & 13941.978 & 1972 & & \\
\hline Financial Self- & Between Group & 5328.910 & 2 & 2664.455 & $535.842^{*}$ \\
\hline \multirow[t]{2}{*}{ Concept } & Within Group & 9795.746 & 1970 & 4.972 & \\
\hline & Total & 15124.657 & 1972 & & \\
\hline Family Self- & Between Group & 4029.688 & 2 & 2014.844 & $03.524^{*}$ \\
\hline \multirow[t]{2}{*}{ Concept } & Within Group & 9836.443 & 1970 & 4.993 & \\
\hline & Total & 13866.131 & 1972 & & \\
\hline Overall Self- & Between Group & 132794.870 & 2 & 66397.435 & $1141.817^{*}$ \\
\hline \multirow[t]{2}{*}{ Concept } & Within Group & 114556.829 & 1970 & 58.151 & \\
\hline & Total & 247351.700 & 1972 & & \\
\hline
\end{tabular}

Significance at .05 level; critical $\mathrm{F}_{2,1970}=2.99 ; \mathrm{N}=1973$

The results presented in table 1 show the mean scores and standard deviations for the three groups of respondents based on their levels of child neglect for each of the self-concept variables. The mean values generally reflect one trend; namely, the higher the level of child neglect, the lower the mean of the self-concept variables.

The results presented in Table 2 shows the actual results of the analysis of variance. The comparison of the three mean values for the three groups for each of the self-concept variables produced F-values of 524.817, 834.312, 404.437, $535.842,403.524$ and 1141.817 for social self, physical self, moral self, financial self, family self and overall self-concept respectively. Each of these F-values is greater than the critical F-value of 2.99 at .05 level of significance with 2 and 1970 degrees of freedom. With these results, the null hypothesis was rejected. This implies that there is a significant influence 
of child neglect on each of the five forms of self-concept and on the overall self-concept.

To understand which group means difference produced the significant influence, a post-hoc pair-wise 'multiple comparison analysis was carried out on the data using Fishers' Least Significance Deference (LSD) analysis. The results of the analysis are presented in Table 3.

Table 3: Fishers' Least Significance Difference (LSD) Multiple Comparison: Influence of Child Neglect on Self-Concept.

\begin{tabular}{|c|c|c|c|c|}
\hline Variable & $\begin{array}{l}\text { Groups } \\
\text { (levels) }\end{array}$ & $\begin{array}{c}\text { Low } \\
(n=672)\end{array}$ & $\begin{array}{l}\text { Moderate } \\
(n=539)\end{array}$ & $\begin{array}{r}\text { High } \\
(\mathrm{n}=762)\end{array}$ \\
\hline $\begin{array}{l}\text { Social Self- } \\
\text { Concept }\end{array}$ & $\begin{array}{l}\text { Low } \\
\text { Moderate } \\
\text { High } \\
\text { MSW = }\end{array}$ & $\begin{array}{l}9.33^{a} \\
17.34^{\star \star} \\
32.37^{\star} \\
3.97\end{array}$ & $\begin{array}{l}2.00^{\circ} \\
7.33 \\
12.56^{*}\end{array}$ & $\begin{array}{l}3.41 \\
1.41 \\
5.92\end{array}$ \\
\hline $\begin{array}{l}\text { Physical Self- } \\
\text { Concept }\end{array}$ & $\begin{array}{l}\text { Low } \\
\text { Moderate } \\
\text { High } \\
\text { MSW = }\end{array}$ & $\begin{array}{l}11.29 \\
23.76^{*} \\
40.64^{*} \\
6.15\end{array}$ & $\begin{array}{l}3.41 \\
7.88 \\
13.75^{\star}\end{array}$ & $\begin{array}{l}5.33 \\
1.92 \\
5.96\end{array}$ \\
\hline $\begin{array}{l}\text { Moral Self- } \\
\text { Concept }\end{array}$ & $\begin{array}{l}\text { Low } \\
\text { Moderate } \\
\text { High } \\
\text { MSW = }\end{array}$ & $\begin{array}{l}9.88 \\
12.04^{*} \\
28.30^{*} \\
\mathbf{5 . 0 2}\end{array}$ & $\begin{array}{c}1.56 \\
8.32 \\
14.27^{\star}\end{array}$ & $\begin{array}{l}3.36 \\
1.80 \\
6.52\end{array}$ \\
\hline $\begin{array}{l}\text { Financial Self- } \\
\text { Concept }\end{array}$ & $\begin{array}{l}\text { Low } \\
\text { Moderate } \\
\text { High } \\
\text { MSW = }\end{array}$ & $\begin{array}{l}8.89 \\
19.56^{*} \\
32.40^{*} \\
4.97\end{array}$ & $\begin{array}{c}2.52 \\
6.37 \\
10.34^{*}\end{array}$ & $\begin{array}{l}3.82 \\
1.30 \\
5.07\end{array}$ \\
\hline $\begin{array}{l}\text { Family Self- } \\
\text { Concept }\end{array}$ & $\begin{array}{l}\text { Low } \\
\text { Moderate } \\
\text { High } \\
\text { MSW = }\end{array}$ & $\begin{array}{l}11.13 \\
11.14^{*} \\
28.23^{*} \\
4.99\end{array}$ & $\begin{array}{l}1.44 \\
9.69 \\
15.12^{*}\end{array}$ & $\begin{array}{l}3.34 \\
1.90 \\
7.97\end{array}$ \\
\hline $\begin{array}{l}\text { Overall Self- } \\
\text { Concept }\end{array}$ & $\begin{array}{l}\text { Low } \\
\text { Moderate } \\
\text { High } \\
\text { MSW = }\end{array}$ & $\begin{array}{l}50.53 \\
24.76^{*} \\
47.76^{*} \\
\mathbf{5 8 . 1 5}\end{array}$ & $\begin{array}{l}10.93 \\
39.60 \\
19.43^{*}\end{array}$ & $\begin{array}{l}19.27 \\
8.34 \\
31.26\end{array}$ \\
\hline
\end{tabular}

a - Group means are placed along diagonal

b- Difference in group means are above diagonal

c- Fishers' t-value are below diagonal

*- Signifcant at .05 level (critical $t=1.96)$

\section{Results}

The results of analysis of variance showing influence of child neglect in each of the components of self-concept variables are presented in tables 1-3. The group means scores and standard deviations are presented in table 1 . While the ANOVA summary is presented in table 2. Table 3 shows the Fishers' LEAST Significant Difference (LSD) multiple Comparison Analysis. The mean score values reflected one trend; that is the higher the level of child neglect, the lower the mean of self-concept variables.

The result presented in Table 2 shows the actual results of the analysis of variance. The comparison of the three mean values for the three groups of the Self-concept variables produced F-values of 524.817, 834.312, 404.437, $535.842,403.524$ and 1141.817 for social self, physical-self, moral self, financial self, family self and overall self concept respectively. Each of these F-values is greater than the critical F-value of 2.99 at .05 level of significance with 2 and 1970 degrees of freedom. With these results, the null hypothesis was rejected. This implies that there is a significant influence of child neglect on each of the five forms of self-concept and on the overall self-concept.

To understand which group means difference produced the significant influence, a post-hoc pair-wise multiple comparison analysis was carried out on the data using Fishers' least Significance Difference (LSD) analysis. The results of the analysis are presented in Table 3.

\section{Disucssion}

The study revealed that child neglect has a significant influence on the students self-concept. This implies that students who were more neglected had low self-concept in terms of their social self, physical self, moral self, financial self and family self respectively. This findings were in line with the previous work of the following (Chapple, Tyler \& Bersani (2005; Egeland et al ; Maughan and Cicchetti 2002; Bolger \& Peterson, 2001). Thus, children who have been neglected are prone to internalizing problems such as low self-concept, depression, social withdrawal, apathy, passivity and helplessness. 


\section{Conclusion}

The study shows that child neglect of any form has a significant influence on the dimensions of self-concept of Senior Secondary school students. This implies that the higher the level of child neglect, the lower the self-concept of the individual (in terms of physical self, social self, moral self, financial self and family self). Hence, there is need for effective intervention that will support the parents and provide the child with cognitive stimulation and emotional warmth that they lack at home. For this reason, high quality child care, home visiting programmes and co-located multi-component services, which target both parents and children may be effective.

\section{References}

Ajake, U. E; Ukpong, E.M; and Jamabo A. (2011). "Sexual abuse and self-concept among senior secondary school students in Cross River State, Nigeria". Annals of modern Education 3 (II) 10 -19.

Bolger, K.E; Kupersmidt, J.B.(1998). "Peer relation \& Self-esteem among children who have been maltreated". Child Development, 69 , 1171 -1197.

Bolger, k.E \& Patterson, C.J. (2001). "Developmental pathway from child maltreatment to peer rejection." Child Development ${ }_{2}$ 72, 549568

Dada, J.A (2002). Legal aspect of medical practice in Nigeria. Calabar: Optimist Publishers.

Ebigbo, P.O. (1990). "The problem of child abuse and neglect in Nigeria and strategies for overcoming them". In Adebayo, O.0. \& Aminu, L.S. (eds) the Nigerian child:Now and in the future. (74-102). Lagos: The Federal Ministry of Health \& Humanservices and united Nations Children's Fund (UNICEF).

Cawson, P; Wattam, C; Broker, S; I kelly, G. (2000) child Maltreatment in the United Kingdom: a study of the prevalence of abuse and neglect. London: NSPCC.

Dubowitz, H. (2004). Childhood neglect. 15 $5^{\text {th }}$ international conference on the prevention of child Abuse and neglect. 19-22 ${ }^{\text {nd }}$ September, Melbourne.

Egeland, B; Yates., T; Appleyard., k.\& van Dulmen., M. (2002). "The long term consequences of maltreatment pathway model to antisocial behavior". Children's services: Social policy, Research \& Practice, 5 (4), 249-260

James, M. (2000a). Child abuse and Neglect: part 1 - Redefining the issues. Australian Institute of criminology Trends \& issues in crime and criminal Justice, 146 http://www.air.gov.au/publications/tandi146.html. 22 nd July, 2013

May - chahal, C. \& Cawson, P. (2005)." Measuring child maltreatment in the United Kingdom: a study of prevalence of child abuse and neglect". Child Abuse \& neglect, 29 (9), 969- 984.

Wetten; W; Lloyd, M.A; Dunn, D.S; Hammer, E.Y (2009). Psychology Applied to Modem life Adjustment in the 21st century. (9th Edition) Belmont: Michele Sordi.

Chapple, C.L; Tyler, K; \& Bersani, B.E (2005). http://digitalcommons.unl.edu/sociologyfacpuls 15th July 2013.

Crounch, J.L; \& Milner, J.S (1993) Effects of child neglect on children. Criminal justice and behavior, 20, 49-65.

DePaul, J., \& Arruabarrena, M.I. (1995). "Behavior problems in School-aged physically abused and neglected children in Spain". Child abuse \& Neglect, 19, 409-418.

Sedlak, A.J.; \& Broadhurst, D.D. (1996). Third national incidence of child abuse and neglect. Rockville, MD: US. Department of health and human services.

DeMuths, S. (2004). "Understanding the delinquency and social relationships of loners". Youth \& Society; 35, 366-392

Straus, M.A. \& Kantor, G.K. (2005). "Definition and measurement of neglectful behavior: some principles and Guidelines". Child Abuse and Neglect, 29, 19-29.

Sulivan, S. (2000). "Current Definitions and Models- A review of child neglect research,1993- 1998. Ottawa, Ontario, Canada, Family violence prevention Unit, Health Canada." Child Neglect

Tanner, k. \& Turney, D. (2003). "What do we know about child neglect? A critical review of the literature and its application to social work practice". Child and family social work, 8, 25-34.

Zuravin, S.J. (1999). "Child Neglect: a review of definitions and measurement research". In .H. Dubowitz (Ed). Neglected children: Research, practice and policy.Thousand oaks, Ca: Sage publications. 24-46.

Isangedighi, A.J; Ajake, U.E. \& Bisong, N.N. (2009)."Child abuse and emotional stability among senior secondary school students in Cross River State, Nigeria". Lawati: A journal of contemporary research 6 (1) 17-25)

Robson, P.J. (1988). "Self esteem-a psychiatric view". British Journal of psychiatery, 153, 6-15.

Sheslow, D.C, Taylor \& Luken, M.A (2005).Developing your self-esteem: kids health. New York: Nemours Foundations.

Conger, J.J (1977).Adolescent and youth psychological development in a changing world. New York: Hamper \& Row.

Maughan, A; \& Cicchetti, D. (2002). "Impact of child maltreatment and interadult violence on children emotion regulation abilities and socio emotional adjustment". Child Development 73 (5) 1525-1542. 